\title{
The role of targeted climate research at the IRI
}

\author{
Bradfield Lyon*, Alessandra Giannini, Paula Gonzalez and Andrew W Robertson
}

\begin{abstract}
Advances in our fundamental understanding of the physical climate system provided the necessary scientific underpinnings for the routine production of reliable seasonal climate forecasts and ultimately, the birth of the International Research Institute for Climate and Society (IRI). While recognizing that the successful adoption of climate information into various decision-making settings requires an iterative approach between the developers and users of that information, since its inception the IRI has also recognized the critical role of basic climate research in generating new climate knowledge. Given its mission, such basic research targets specific regions and questions that are framed by practical considerations of how climate variations are impacting, or may impact, various sectors of society. Analogous to its role in underpinning the development of seasonal forecasts, an enhanced understanding of relevant aspects of the physical climate is viewed as a critical input to the larger process of developing effective strategies for the management of climate-related risks. Here, four examples of targeted climate research undertaken at the IRI are presented covering a range of time scales, from sub-seasonal variability to long-term climate trends. A diverse set of geographic locations is considered, which includes the Sahel, southeastern South America, the Philippines and Indonesia. These four examples were selected to indicate the broad range of use-inspired basic research questions that have been addressed in regions where the IRI is engaged in a broader set of activities to develop actionable climate information. While many institutions are engaged in basic climate research, having the expertise and capacity to do so within the IRI provides it with the necessary flexibility to target its work towards specific climate-related questions in specific regions of the world.
\end{abstract}

Keywords: Climate; Climate research; Climate knowledge; Climate and society; Climate risk management

\section{Background}

The management of climate risks first requires an understanding of the physical characteristics and behavior of relevant aspects of the climate system. The provision of such knowledge is the role of climate science and while there are many institutes around the globe engaged in basic climate research, it has long been recognized as an important core activity within the International Research Institute for Climate and Society (IRI). While the mission of the IRI certainly requires the interaction and collaboration with a broader community, there are multiple advantages to the institute for having the expertise and capacity necessary to conduct basic climate research in-house. Primary among these advantages is that it allows the IRI the necessary flexibility to target such research towards answering fundamental climate questions that arise in specific regions where it is engaged in broader climate

\footnotetext{
* Correspondence: blyon@iri.columbia.edu

International Research Institute for Climate and Society; The Earth Institute, Columbia University, 61 Route 9 W, Palisades, NY 10964, USA
}

risk management initiatives. The results from such useinspired basic research are thus viewed as an important input to a continuum of climate information that is ultimately needed to manage risk. However, just as advances in our understanding of the physical climate system provided the necessary scientific underpinnings for the routine production of reliable seasonal climate forecasts (and indeed, the birth of the IRI), so too does effective climate risk management require fundamental knowledge of the climate system itself.

In this paper, four examples are presented which capture the range of basic climate research that has been conducted at the IRI as motivated by specific climate questions that arose from targeted regions where the IRI is working. Paralleling the broad interests of the IRI, these examples cover a range of time scales. The first example is research on climate trends in a key agricultural area of southeast South America where summer rainfall has undergone an upward trend for more than a halfcentury. Partly in response to this greater availability

\section{穴}

(c) 2014 Lyon et al.; licensee Springer. This is an Open Access article distributed under the terms of the Creative Commons Attribution License (http://creativecommons.org/licenses/by/2.0), which permits unrestricted use, distribution, and reproduction in any medium, provided the original work is properly credited. 
of moisture, particularly in historically more marginal farming areas, agricultural activity in the region has expanded substantially. But will the increase in rainfall last? The answer has obvious implications for agriculture. Providing an answer requires basic climate science research: What has been driving the long-term increase in rainfall in southeast South America? The second example is from the Sahel, where protracted droughts during the 1970s and 1980s are a well-documented example of decadal scale climate variability, which had substantial impacts across the region. However, determining the underlying cause of the increased occurrence of drought has taken decades of research. In particular, the potential role of human activity and associated land cover change in forcing the drought has been debated since the 1970s. Did changes in land cover contribute to the establishment of the droughts, or were they primarily the result of other factors? It's a basic science question, with the results pertinent to landuse policy and planning, as just two examples. The third case comes from the Philippines and shifts to seasonal time scales. El Niño events are frequently associated with droughts in the Philippines, which can substantially impact the agriculture and water sectors. As part of a project aimed at enhancing water management practices at the Angat Reservoir, the largest multi-use water supply system in the metro Manila region, IRI climate scientists were tasked with determining if the development of skillful seasonal forecasts of the inflow to the reservoir were possible. A critical first step was to investigate the seasonally varying influence of the El Niño-Southern Oscillation (ENSO) on rainfall in the region. Finally, switching to sub-seasonal time scales, rainfall variability in Indonesia is considered. From the national economy down to individual livelihoods, Indonesia is highly reliant on agriculture, which is affected not only by the variability of seasonal rainfall but also its timing and spatial distribution. Based on an agronomic definition of monsoon onset, basic research was undertaken at the IRI evaluating the predictability of the onset of the rainy season across Indonesia. In its most intensively cultivated area, Java, spatial variations in rainfall during El Niño events (typically associated with drought) were investigated, revealing major differences over short distances, with some areas actually being anomalously wet in El Niño years. Incorporating the climate knowledge gained through these studies into specific decision-making and planning settings clearly requires additional work. However, the provision of such knowledge is an essential element of that broader process, pointing to the important role that targeted climate research has at the IRI.

\section{Summer precipitation trends over southeastern south America}

South Eastern South America (SESA), which includes Uruguay, southern Brazil, Paraguay and northern Argentina, is the transition zone between the wetter monsoon core associated with the South Atlantic Convergence Zone, and the drier Andean and Patagonian regions (Figure 1a). SESA stands out for being one of the regions with the strongest observed $20^{\text {th }}$ century precipitation trends in the entire world (Liebmann et al. 2004; Haylock et al. 2006; Barros et al. 2008; Seager et al. 2010), as can be shown using IRI's Time Scales Decomposition Maproom (Greene et al. 2011). The strong wetting in this region (Figure 1b) has had a significant economic impact, due to the subsequent expansion of its agricultural frontiers (Barros et al. 2008; Viglizzo and Frank 2006). In addition to the longterm trend, the climate of this region is characterized by very strong interannual variability (Figure 1c) in both summer (December-February) and winter (June-August) seasons. This variability can have substantial impacts on the agriculture, water and energy sectors in its own right. It has been established that interannual climate variability in SESA is primarily driven by associations with the ENSO phenomenon (Ropelewski and Halpert 1996), and is also influenced by sea surface temperature variations in the Indian Ocean (Chan et al. 2008) as well as atmospheric variability originating in higher latitudes (Zhou and Lau 2001; Silvestri and Vera 2003). Thus, while the long-term increase in rainfall has been beneficial economically, it is not clear what has been driving this change and therefore whether or not more abundant rainfall will continue in the future. Answering that question requires the evaluation of multiple factors.

As a starting point, an analysis was performed (Gonzalez et al. 2012) of the consistency of the trend and variability between a gridded precipitation dataset from the Global Precipitation Climatology Center (GPCC) and a set of station-based, century-long records from SESA. Both the station and gridded datasets show good agreement on the temporal variability of summer precipitation and its spatial patterns for different timescales. The magnitude of the wetting trend in SESA observed for the DecemberFebruary season in GPCC over the period 1901-2000 is more than $10 \mathrm{~mm}$ per decade, highly consistent with the trend observed in the station-based SESA average (Figure 2). To then begin the exploration of the possible causes of the observed trend, simulations of the current climate in several general circulation models (GCMs) used in the Coupled Model Intercomparison Project Phase 5 (CMIP5) were examined. These models include observed changes in greenhouse gases (GHGs). A first step was to examine the models' ability to reproduce the observed trend in rainfall. It was found (Figure 3 ) that none of the simulations from these models were able to successfully capture a rainfall trend across SESA of similar magnitude to what is observed (Seager et al. 2010; Gonzalez et al. 2013). The reasons why this large ensemble of state-ofthe-art climate models fails to simulate the SESA trend 


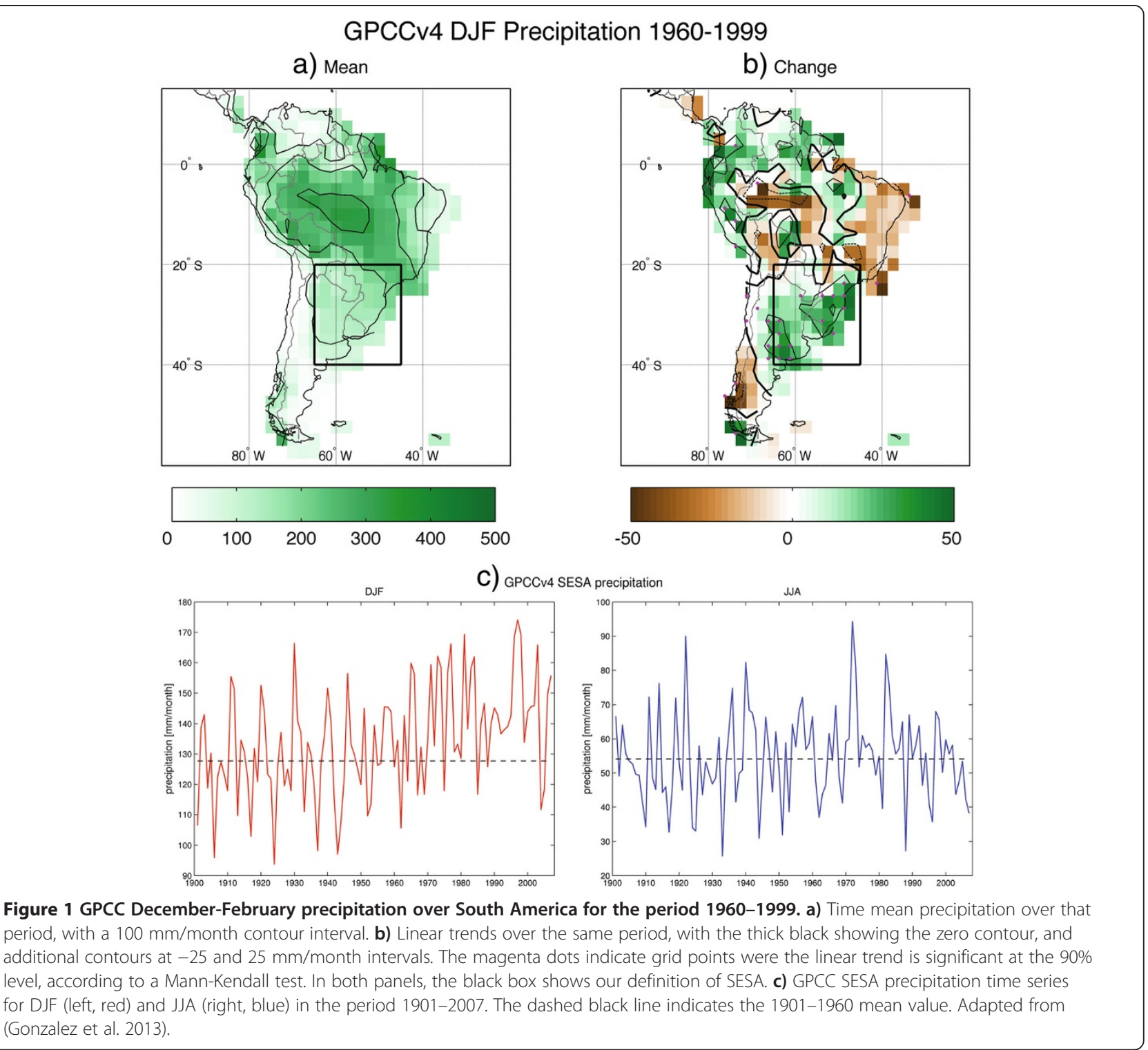

remain unclear. Nonetheless, the results prompted a different approach in the investigation of the rainfall trend.

Upon closer inspection of the observations, it was seen that the rainfall trend over the last century was most pronounced during the more recent period from 19601999. In addition, there was also a marked contrast in trends when comparing the December-February versus June-August seasons (Figure 1c). While the figure shows there is large year-to-year variability, SESA precipitation during December-February appears to start rising most prominently during the last few decades of the $20^{\text {th }}$ century, whereas the June-August time series shows a very different behavior including very little evidence of a trend. This observation, together with previous modeling studies (Kang et al. 2011), suggested that ozone depletion might have been an important driver of the precipitation changes, since unlike the effect of GHGs increases, the ozone depletion impact on the troposphere is restricted to the summer season (December-February). To explore this possibility in more detail, a hierarchy of experiments using 6 GCMs was undertaken (Gonzalez et al. 2013) to examine the influence of stratospheric ozone depletion on SESA precipitation trends. That study found that for all the models analyzed, decreased ozone concentrations during the period 1960-1999 was manifested in the models as an increase in SESA rainfall (Figure 4). Additionally, for the subset of the same models that also contained an experiment where only changes in greenhouse gases concentrations were considered, the modeled precipitation trends were not only smaller than those in the ozone-only runs, but in some models they were even of opposite sign of that seen in observations. The consistency of the model 


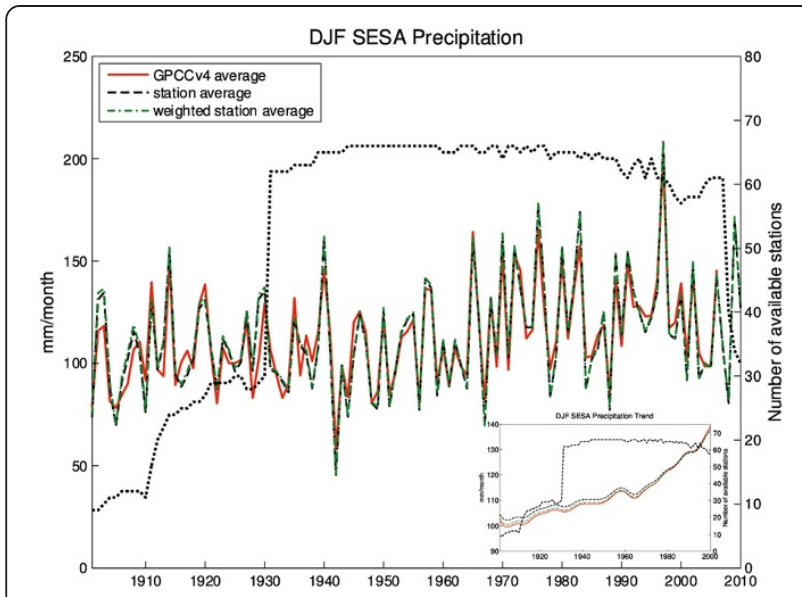

Figure 2 SESA regional DJF precipitation index from GPCC (red line) compared with two different station-based indexes: a standard average (black line) and an area weighted average (green line). The dashed line corresponds to the right axis and indicates the number of available precipitation stations for each year. The inset in the bottom right corner presents the non-linear trends obtained for the same time series. From (Gonzalez et al. 2012).

rainfall trends in the ozone-only experiments and lack of consistent influence of GHGs suggests that the former may be playing the dominant role in driving the observed rainfall increase during summer. In all the models analyzed, however, the magnitude of the rainfall increase was too small relative to what has been observed, as evidenced by the black vertical lines in Figure 4 that describe the complete ensemble range. Further research is being conducted to investigate this aspect in more detail.

An important implication of these results from a practical point of view is that, due to the expected recovery of stratospheric ozone concentrations, rainfall in SESA may be expected to level off in coming decades, or possibly even decrease, as the influence of depleted ozone levels on rainfall weakens. Given the high level of agricultural activity in the region, this could obviously have important economical consequences. This research also brings to light an important, broader, issue regarding the use of the CMIP5 climate change projections to explore future climate scenarios. Diagnostic research into the behavior of individual climate models can potentially identify problems in their performance in a given region. In regions such as SESA, reliance on these models alone does not allow for other important processes, such as ozone depletion, that need to be modeled if they are to capture important climate processes affecting the region. Thus, based on the results of the targeted climate research undertaken for the region, alternative methods are now being explored to create precipitation scenarios for the near-term future (coming 10-30 years) in SESA that don't rely on CMIP5 model output alone. One approach to assess possible changes in climate in the nearterm is to generate a set of decadal stochastic simulations (Greene et al. 2012) for SESA rainfall based on different trend scenarios that include the effects of both greenhouse gases increases and ozone recovery. From an applications perspective, it is planned to use these simulations as inputs to crop models that can provide scenarios for future crop yields and an associated range of economic consequences for the region. Overall the climate research to explore drivers of the recent rainfall increase has broader implications for agriculture in the region.

\section{Looking back to plan ahead in the Sahel Ending the debate on the cause of protracted Sahel drought}

Since the early 1970s, when recognition that persistent drought was contributing to an environmental crisis, the Sahel, (broadly defined as the semi-arid belt just south of the Sahara, from the Atlantic coast of Mauritania and Senegal to the Red Sea coast of Sudan and Eritrea), has elicited special attention in climate research and in policy dialogue. For example, the Sahel was one of only 5 regions worldwide picked for in-depth focus in the first Assessment Report of the Intergovernmental Panel on Climate Change. While these activities provided a determined focus on the region, to a large extent they revolved around contrasting scientific explanations of the root cause of the crisis. Did severe drought result in serious degradation to the environment, or did degradation of the environment contribute to the severity of the drought?

The vulnerability of society to climate variations in the Sahel entered the global stage when recurrent droughtinduced food insecurity led to significant loss of human life in the early 1970s in the western Sahel, and in 1984 in Ethiopia. Early on, it was postulated that the persistence of drought since the 1970s was caused by depletion or degradation of land resources driven by rapid population growth. Extension of agriculture into marginal land, overgrazing by herds of livestock that exceeded the land's "carrying capacity" and woodcutting for fuel were all invoked to explain the baring of the soils, which was hypothesized to put in motion a positive bio-geophysical feedback that further reduced precipitation and vegetation cover (Charney 1975). The combination of extreme drought and land degradation in the 1970s spawned the formation of regional and global institutions. The most notable action was the grouping of the 9 West African Sahelian countries from Cape Verde eastward to Chad into the political CILSS region, and the foundation of its scientific and technical arm, the Agrhymet regional center in Niamey, Niger. The United Nations (UN) Conference on Desertification was held in Nairobi in 1976 and the Convention to Combat Desertification was presented 


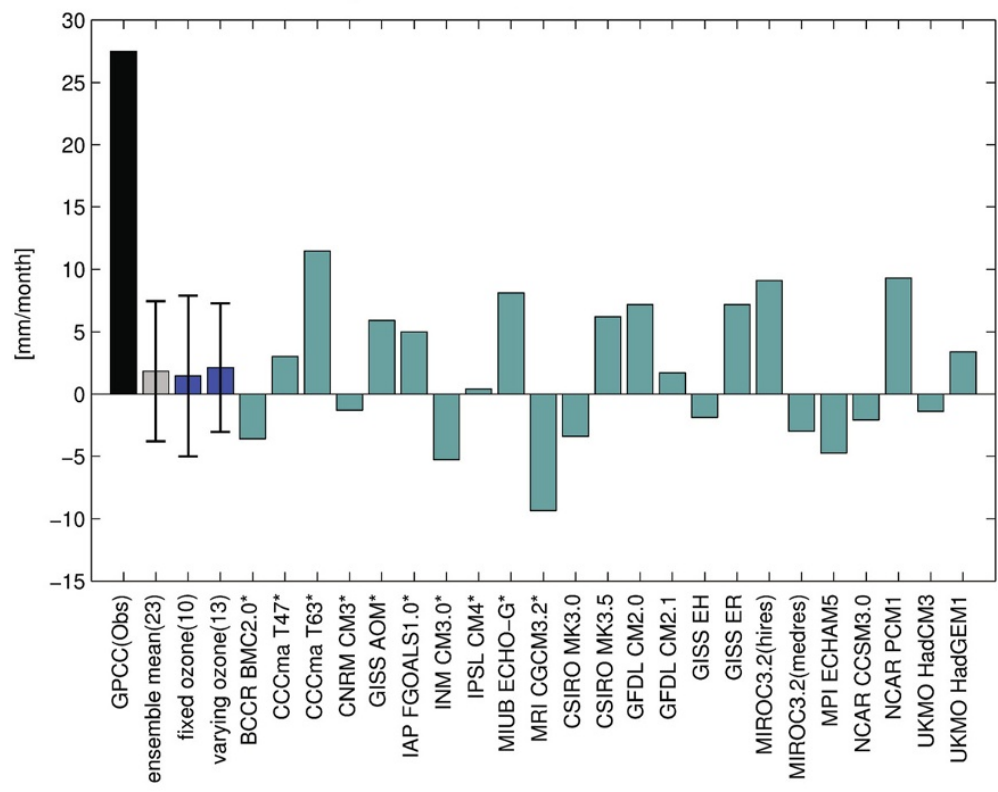

b) CMIP5 historical (r1i1p1) vs. observations

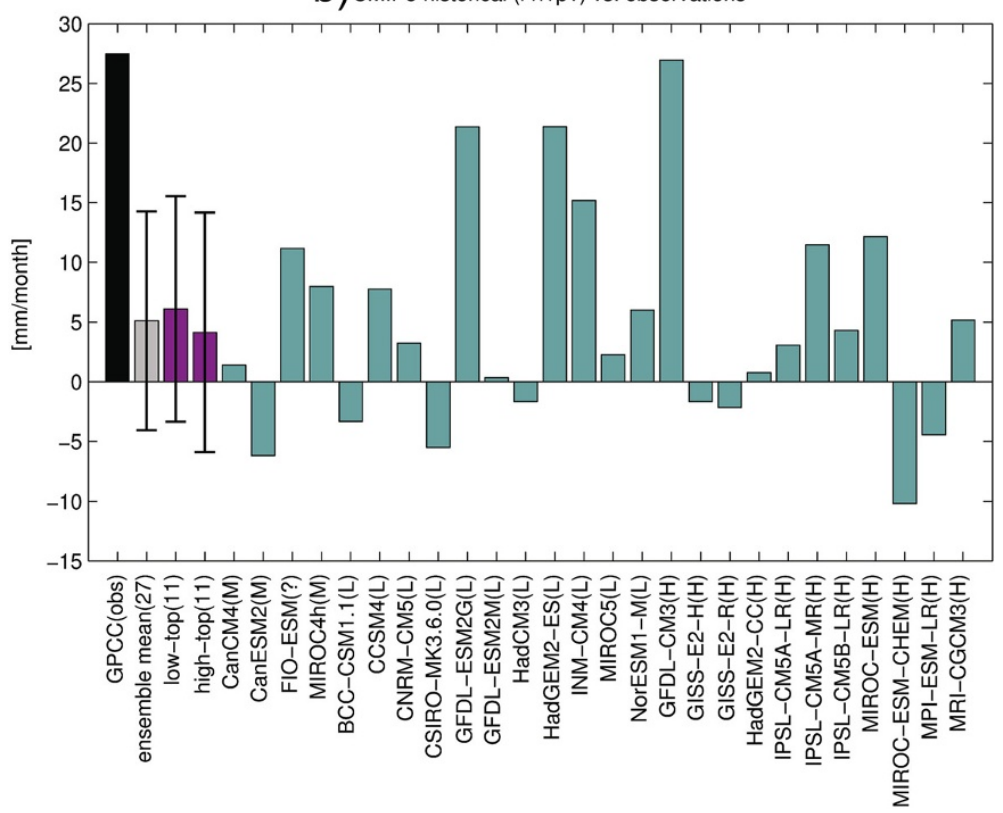

Figure 3 Changes in SESA precipitation in state-of-the-art CGCMs for the period 1960-1999. a) 'run1' from the 20C3M CMIP3 simulations. Models with an asterisk did not include time-varying ozone concentrations. b) a single run from the historical CMIP5 simulations. The letters $L, M$, and $H$ after the model name indicate the relative vertical resolution of the model: low, middle and high, respectively. In both panels the black bar shows the observed change from the GPCC dataset and the grey bars show the multi-model ensemble mean. When present, the thin black lines represent 1 standard deviation from the inter-model spread. The number between parentheses represents the size of the model ensemble for each group. From (Gonzalez et al. 2013).

at the UN Conference on Sustainable Development in Rio in 1992.

While the above activities were largely driven by the emergence of drought in the 1970s, climate predictability as a research effort has come into focus only in more recent decades. The UK Met Office initiated its effort, the longest standing in donor countries, in 1991 (Folland et al. 1991) on the heels of demonstration by some of its scientists (Folland et al. 1986; Palmer 1986; Rowell et al. 1995; Rowell 1996) that a global pattern of sea surface 


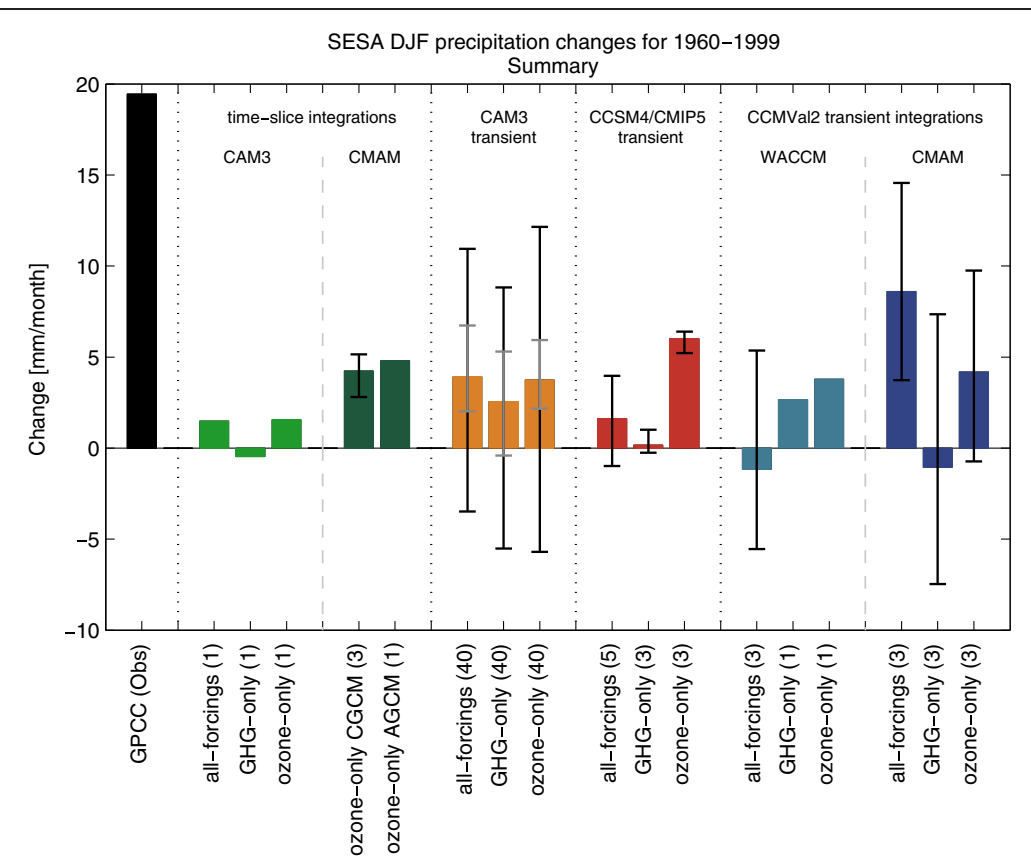

Figure 4 Summary of observed and computed changes in SESA precipitation, for the period 1960-1999. Black is the observed change from the GPCC dataset. The number of ensemble members is shown in parenthesis after the label of each integration, which indicate if ozone or GHG are time-varying. The black vertical lines show the complete range of each ensemble and for the 40-member CAM3 ensemble (orange), with the interquartile interval also shown in grey. Adapted from (Gonzalez et al. 2013). Additional details regarding the integrations and model configurations are shown in Figure 5 and Table 1 in (Gonzalez et al. 2013).

temperature (SST) anomalies (departure from average conditions) was all one needed to reproduce drought in the Sahel in an atmospheric climate model. Despite the pioneering work of the Malian Direction Nationale de la Météorologie (Diarra and Dibi-Kangah 2007) to provide climate information to farmers (responding to rural communities quest to restore order in the midst of chaos engendered by persistent drought) the seasonal prediction effort was not picked up again at regional level until 1998, 2 years after the birth of the IRI and just after the largest El Niño of the $20^{\text {th }}$ century attracted significant attention to seasonal forecasting.

The advent of the West African seasonal climate outlook forum in May 1998, better known as PRESAO from its French acronym, emerged from this new emphasis on seasonal prediction. The forum has taken place yearly since the first one was convened in Abidjan, Ivory Coast in that year (ACMAD 1998). Since the forum's inception, IRI climate scientists have participated in every event, contributing significantly to capacity building in the area of statistical seasonal forecast production by national meteorological service participants. In addition, with PRESAO as its entry point, the IRI has built a presence in the region that has gone well beyond seasonal climate prediction. IRI has formally contributed to the organization of e.g. the International conference for the reduction of vulnerability to climate change of natural, economic and social systems in West Africa, held in Ouagadougou in January 2007, and of a Regional training workshop on the variability and predictability of agro-hydro-climatic characteristics of the West African rainy season, held at Agrhymet, in Niamey, Niger in May 2012. IRI staff have continuously capitalized on travel to the region to foster informal interaction with young climate researchers at universities. Notably, these interactions have benefited from independent support from START - the global change SysTem for Analysis, Research and Training resulting in advances in the dynamical characterization of sub-seasonal variations in precipitation, as well as in the communication of climate information for disaster relief.

At IRI, the research needed to ground seasonal forecasts in a dynamical understanding of the physical climate system progressed in parallel to the outlook forums. After about a decade of inconclusive model simulations of the possible cause of the protracted Sahel drought (Rowell 1996), earlier results (Folland et al. 1986) were finally confirmed (Giannini et al. 2003): the $20^{\text {th }}$ century evolution of Sahelian climate, specifically the abrupt transition from anomalously wet 1950 s and 1960 s to anomalously dry 1970s and 1980s (and the partial recovery since), could be simulated given only a specification of the global SST field (Figure 5). Similar results were subsequently reproduced 


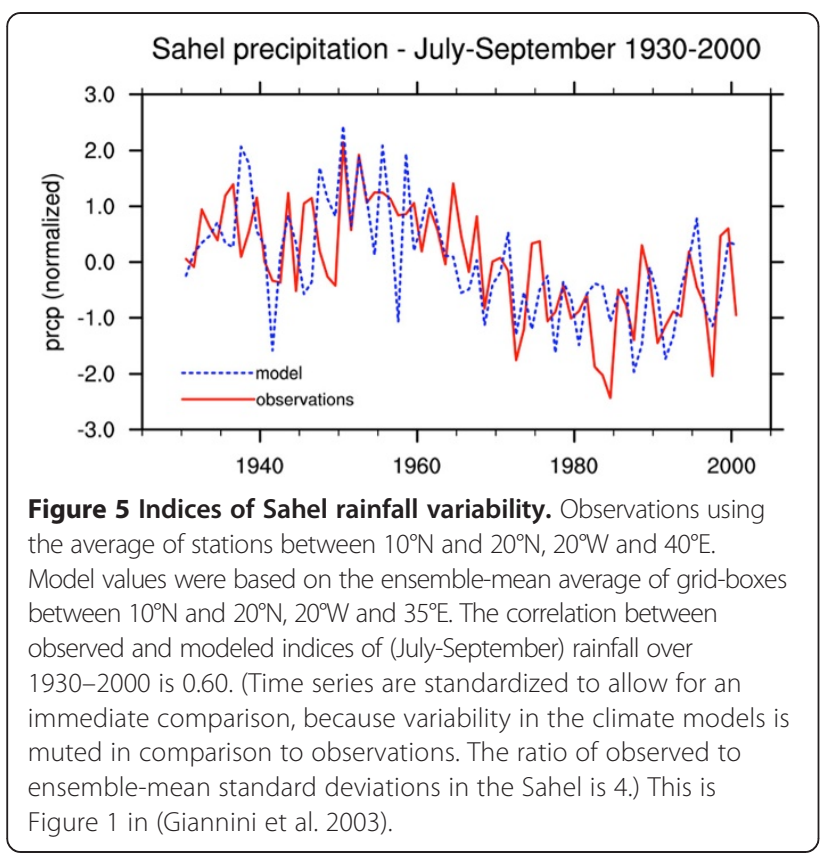

using other climate models (Bader and Latif 2003; Lu and Delworth 2005), cementing the conclusions. These results had fundamental implications regarding our understanding of climate variations in the Sahel on different time scales: first, the persistence of drought during the 1970s and 1980s had not been caused by land use change, and second, the connection of Sahel drought to global SSTs indicated that the climate of the Sahel was indeed potentially predictable, bolstering seasonal climate prediction efforts.

\section{Past behavior and future insights}

The predictability of seasonal rainfall in the Sahel largely hinges on first predicting regional and global patterns of SSTs (Goddard and Mason 2002; Ndiaye et al. 2008). This is challenging because in order to predict the JulySeptember rainy season one needs to first demonstrate skill in predicting SSTs during the boreal summer, a time of year when predictability is often low, relative to the winter season. As elsewhere, ENSO provides the most consistently predictable signal for rainfall in the Sahel (Ndiaye et al. 2011). However, it also provides an "analogue" for the consideration of climate change. Applying the theoretical understanding developed among others (Neelin et al. 2003; Held and Soden 2006), it has recently been shown (Giannini et al. 2013) that the past, present and future of Sahelian climate variability, observed and modeled, can be captured in a simple relation: the difference in SSTs between the sub-tropical North Atlantic and the global tropical oceans (Figure 6). As oceans warm local rainfall intensifies, warming the atmosphere and making it more stable elsewhere, which favors reduced rainfall and potentially leads to drought over land. However, warming oceans also potentially provide an increased moisture supply for monsoons around the globe, helping to overcome the higher stability. Depending on which factor dominates can determine whether rainfall decreases or increase in different regions of the globe.

The occurrence of the late $20^{\text {th }}$ century drought in the Sahel is consistent with the lack of warming of the North Atlantic precisely at the time of emergence of anthropogenic warming of the oceans. The lack of Atlantic warming is currently understood to have been in significant part due to the cooling effect of aerosols (Rotstayn and Lohmann 2002; Chang et al. 2011). Adoption of legislation aimed at curbing air pollution in North America and Western Europe has helped reduce aerosol concentrations, which has in turn has been a contributor to the subsequent warming of the North Atlantic, and consistently, for the current "partial recovery" of Sahelian rainfall to take place.

While the crisis precipitated by persistent drought in the Sahel in the early 1970s has left an indelible mark, it is important to recognize that while the drought may have been in part anthropogenic, as is implied by the role of greenhouse gases in warming the oceans, and of aerosols providing Atlantic cooling to contrast the warming, future climate change does not necessarily equal continued drought in the Sahel. In fact, the regional recurrence of repeated episodes of flooding, urban and rural, during recent rainy seasons, catalyzed the collaboration between the UN World Food Programme and IRI. Information on underlying climate trends can inform WFP interventions in disaster relief and recovery. The IRI-WFP partnership to date has exploited respective expertise in the collection and analysis of livelihood surveys at household level, and in the dynamical interpretation of climate trends, to define the historical context of the climate sensitivity of food security at country level, in Mali and Senegal. It has also facilitated the participation of climate service providers in discussions around drought index insurance.

Going forward we should remain vigilant to emergent trends in oceanic variability and in Sahel rainfall variations on annual down to sub-seasonal time scales. It is equally important that we remain flexible in charting adaptation strategies for the region. Coupled with the partial recovery of the rains from changes in atmospheric and oceanic conditions around the globe a component of the re-greening of the Sahel may, indeed, have resulted from human ingenuity in land resources management through the adoption of simple, but efficient measures to exploit rainfall such as agro-forestry and soil and water conservation (Reij et al. 2005). Thus, while our understanding of rainfall variability in the Sahel has required a considerable effort in climate science (Giannini et al. 2005; Giannini et al. 2008; Giannini 2010; Biasutti and Giannini 2006; Biasutti et al. 2008; 


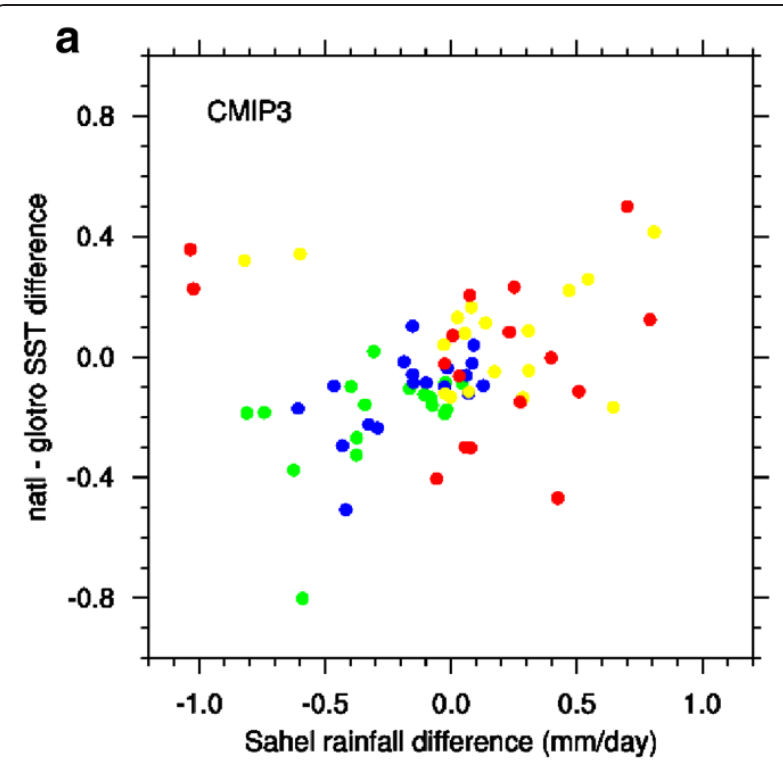

b

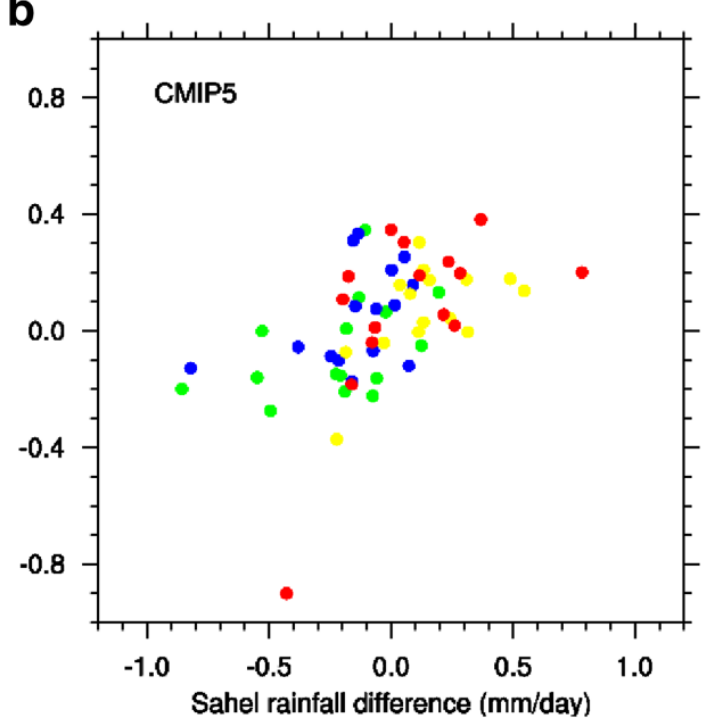

Figure 6 Simulated change in Sahel rainfall in (a) CMIP3 and (b) CMIP5 models against the change in (surface air) temperature difference between the subtropical North Atlantic and the global tropical oceans. All averages are taken July-September. Green dots identify the change between the end of the 20th century (CMIP3/ 20c3m, CMIP5/historical) and the 'pre-Industrial' control, blue dots the change between end and beginning of the 20th century, yellow dots the change between the middle of the 21st century (CMIP3/A1B scenario, CMIP5/RCP4.5) and the end of the 20th century, and red dots the change between end of the 21st and 20th centuries-we averaged 100 years of pre-Industrial control, and up to 3 ensemble members of the 20th and 21st century simulations when available. There are 17 models in the CMIP3 scatter, 15 in the CMIP5 scatter. This is Figure 1 in (Giannini et al. 2013).

Tippett and Giannini 2006; Moron et al. 2008a; Moron et al. 2008b; Greene et al. 2009; Hansen et al. 2011), incorporating these results into policy and planning is indeed a multi-disciplinary effort.

\section{The seasonally varying influence of ENSO in the Philippines}

In many tropical land areas of the globe El Niño events are frequently accompanied by drought (Lyon 2004; Lyon and Barnston 2005), the Philippines being one of them. During an El Niño, drought conditions in the Philippines are most widely expected in the boreal fall and winter seasons when these events are typically strongest. Once developed, drought then frequently persists into the subsequent early spring. However, the nature of the impacts of El Niño (and La Niña) on regional rainfall variations around the globe is tied to the interaction between the life cycle of ENSO events and the annual cycle of rainfall within a given area. For example, El Niño-related drought in the Philippines during the fall occurs during the northeast monsoon season. However, the development stage of ENSO events frequently takes place earlier, during the boreal summer, when the southwest monsoon is the dominant circulation feature. The impact of ENSO on seasonal rainfall during the summer season in the Philippines has not received much attention by researchers. In addition, the Philippines are substantially affected by tropical cyclones, which frequently occur from summer into the fall. These storms not only bring damaging winds and storm surges to the Philippines, they also typically generate very high amounts of rainfall, thereby affecting seasonal average precipitation. This leads to the additional question of how ENSO influences not only seasonal rainfall but also the behavior of tropical cyclones over the course of the year.

These basic questions regarding the seasonally varying influence of ENSO on Philippine climate arose during early stages of an IRI project in the region focused on improving water management practices for the Angat Resevoir in Luzon, which provides water for over 8 million people in the Metro Manila area. Since inflow to the reservoir can be substantially affected by the state of ENSO, better management of water within the reservoir system relied fundamentally on a better understanding how inflows to the system varied over the course of the year, particularly when an ENSO event was underway. Working with climate data provided by the Philippine Atmospheric, Geophysical and Astronomical Services Administration (PAGASA) and in collaboration with some of their climate scientists, a study addressing these topics was undertaken. Previous work had provided some hints that the influence of ENSO on boreal summer rainfall in the Philippines might be different from that during the boreal fall and winter (Walker \& Bliss 1932; Kiladis \& Diaz 1989; Kripalani \& Kulkarni 1997) but additional research was needed to provide a more definitive answer.

In terms of seasonal rainfall variability, an analysis of the observational data revealed that during the boreal summer months of July-September of El Niño years many locations of the north-central Philippines actually 
experienced a statistically significant occurrence of above average rainfall (Figure 7) before the expected below average conditions spread across the region during the boreal fall (Lyon et al. 2006; Lyon \& Camargo 2009). Generally opposite conditions were observed during La Niña years (not shown), when rainfall was found to be below average across much of the north-central Philippines in July-September before becoming wetter than average in the subsequent fall. The essential underlying mechanisms are related to the formation of an anomalous low-level cyclonic (anticyclonic) circulation over the western North Pacific, to the east of the Philippines, during the onset phase of El Niño (La Niña) events in boreal summer. One consequence of this anomalous circulation is an enhancement (reduction) in the westerly component of the summer monsoon flow, extending from the Bay of Bengal eastward across the north-central Philippines during El Niño (La Niña) (Lyon and Camargo 2009; Juneng \& Tangang 2005). This anomalous circulation appears to be a response to enhanced rainfall occurring primarily west of the date line during the onset phase of ENSO. During boreal fall the area of enhanced rainfall associated with the formation of the anomalous cyclonic circulation the previous summer is located further to the east, and an anomalous anticyclone (cyclone) develops in the vicinity of the Philippines, which tends to reduce (increase) rainfall there (Wang and Zhang 2002) and thus leading to the reversal in the ENSO rainfall signal.

Changes in the behavior of tropical cyclones through the calendar year were also investigated during both El Niño and La Niña events. Previous studies have shown that during El Niño (La Niña) years, tropical cyclones generally tend to develop further to the southeast (northwest) of their climatological mean genesis locations (Chan 1985; Chen et al. 1998; Wang and Chan 2002; Chia and Ropelewski 2002). This shift in genesis location with ENSO leads to different track types in El Niño and La Niña years (Camargo et al. 2007a), with a tendency for more long lived and intense typhoons occurring in El Niño years, and fewer and shorter-living tropical cyclones in La Niña years (Camargo \& Sobel 2005). However, these previous studies were not focused solely on storms that impacted the Philippines. A few studies have shown statistically significant differences in landfall rates in the northern Philippines between El Niño and La Niña events with more, intense typhoons making landfall in northern Luzon (northern Philippines) in La Niña years (Saunders et al.

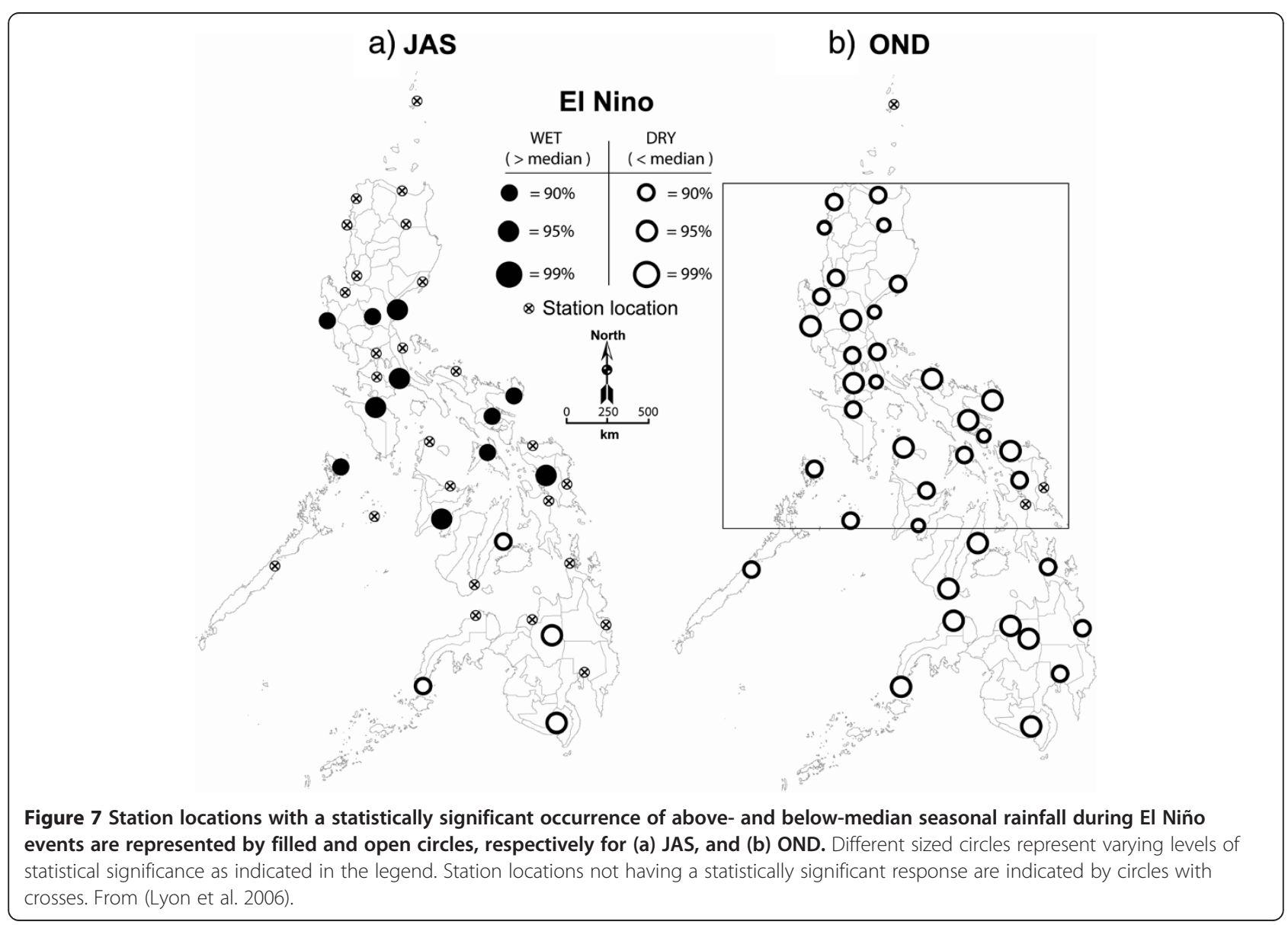


2000), but they did not focus on the seasonal evolution of ENSO in the analysis. To address the issue in more detail, variations in cyclone tracks in the vicinity of the Philippines were explored using over 50 years of historical data archived by the Joint Typhoon Warning Center. The results showing the track differences (El Niño minus La Niña) years is shown in Figure 8 for the July-September and October-December seasons. The figure shows a tendency for enhanced (reduced) tropical cyclone activity during July-September of El Niño (La Niña) years. These tendencies then reverse during October-December.

The factors in the atmosphere that affect the genesis of tropical cyclones were subsequently explored by looking at the individual terms that contribute to an index developed to estimate the potential for tropical cyclone development (Emanuel and Nolan 2004; Camargo et al. 2007b). There were substantial seasonal variations in this index during El Niño and La Niña years (Figure 9). It was discovered that there was a greater potential for the development of tropical cyclones in the Philippines during the summer (July-September) of El Niño events, with this tendency then reversing during October-December. Generally opposite behavior was found during La Niña events, again as a function of season. The largest contribution to this change in tropical cyclone behavior with season was found to be atmospheric moisture availability that varied in a consistent manner with the circulation features identified in the first stage of the research (Lyon and Camargo 2009).

Overall, the study provided important insights to the variability of the seasonal climate of the Philippines relevant to the water management (the main activity of the IRI project) as well as hazards communities. In addition, the collaboration between IRI and PAGASA scientists helped to both build regional capacity in climate analysis and prediction and to establish important partnerships for subsequent work in the region. (a)

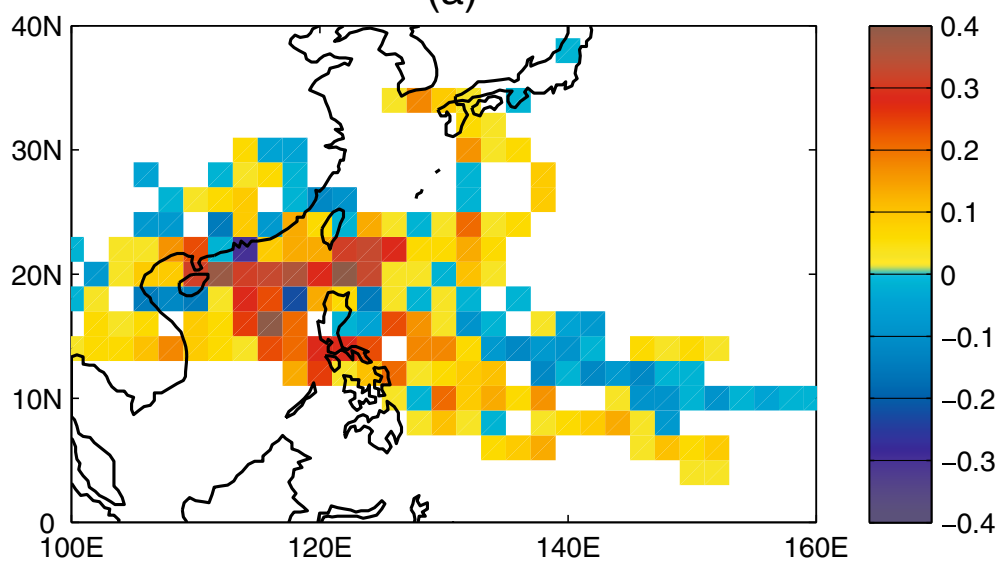

(b)

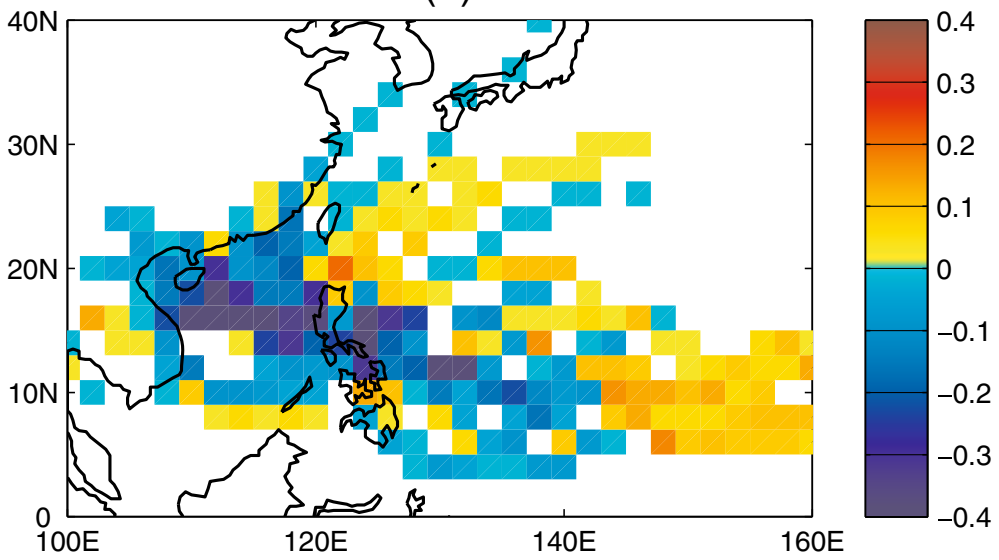

Figure 8 Composite tropical cyclone track differences (El Niño-La Niña) for a) July-September and b) October-December. From (Lyon and Camargo 2009). 


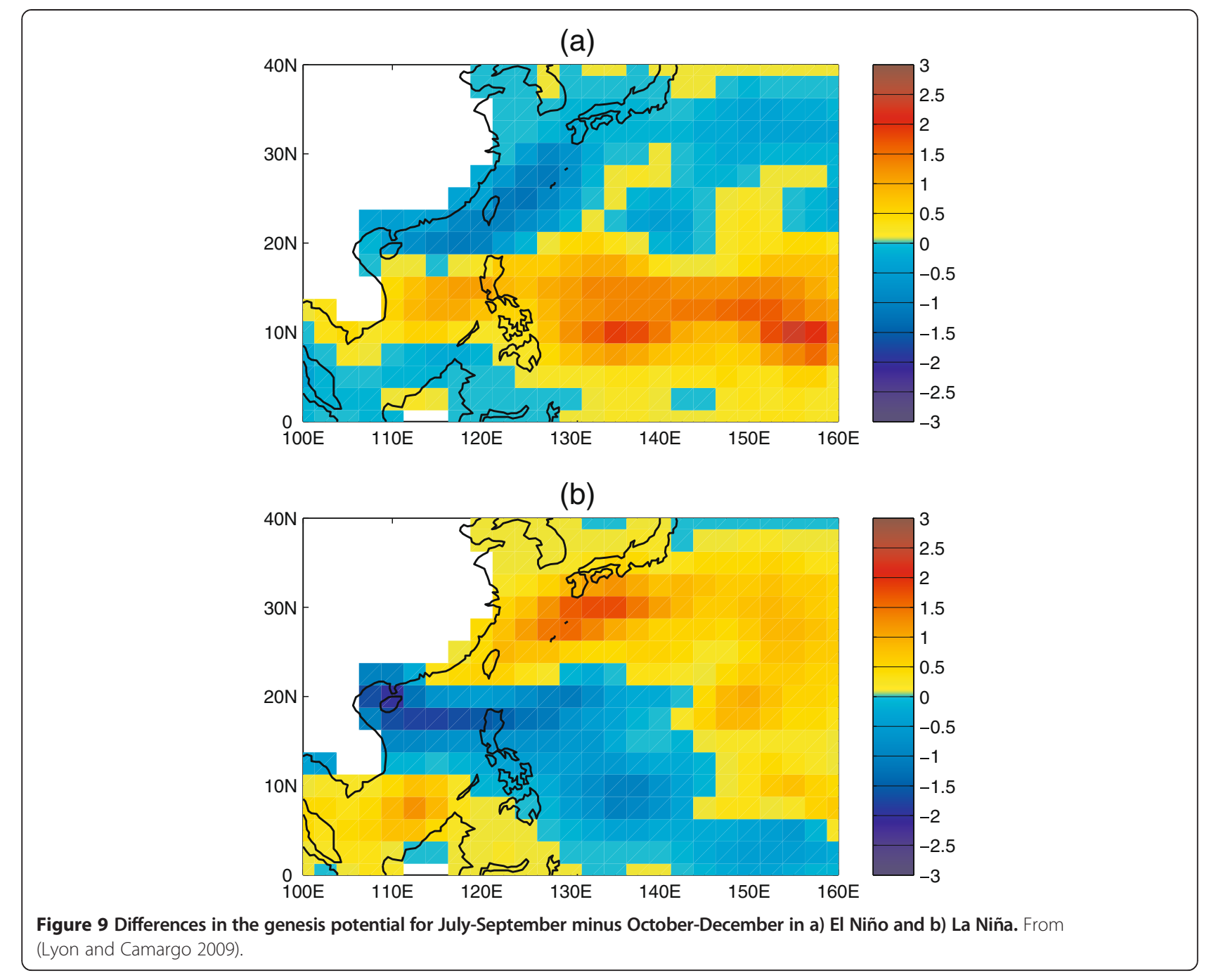

ENSO, monsoon onset and daily rainfall variability over java, Indonesia

ENSO has a pronounced impact on Indonesian rainfall, leading to some of the highest seasonal forecasting skills seen in the IRI operational forecasts, particularly during the October-December season (Barnston et al. 2010). This pronounced ENSO impact over Indonesia during the monsoon-onset transition season is well known, and understood through the impacts of ENSO-related SST anomalies both in the equatorial Pacific, and those around Indonesia (Hendon 2003). The high level of seasonal prediction skill over Indonesia provides good opportunities for climate risk management in the region and, in consultation with colleagues at Bogor Agricultural University, demonstration projects for rice growers in an important rice growing district of west Java have been developed, along with pilot fire risk management effort in central Kalimantan (Ceccato et al. 2010). These projects required a closer examination of rainfall predictability on smaller temporal scales than seasonal averages and on smaller spatial scales than, for example, the approximately $300-\mathrm{km}$ grid scale of the monthly IRI seasonal forecasts (Barnston and Tippett 2014). In particular, information about weather characteristics within in a three-month season is more pertinent for agriculture and fire management than seasonal averages. This is especially true in the agricultural sector where there is substantial interest in information regarding the onset date of the monsoon and dry-day frequency within it (Robertson et al. 2014).

The following subsections describe two examples of downscaling diagnostic research over Indonesia that was spawned by the demand for more detailed climate information in the above projects.

\section{Seasonal predictability of weather statistics and monsoon onset date over java}

Figure 10 shows the anomaly correlation coefficient skill of climate model seasonal hindcasts for the SeptemberDecember season, downscaled to the station scale using 


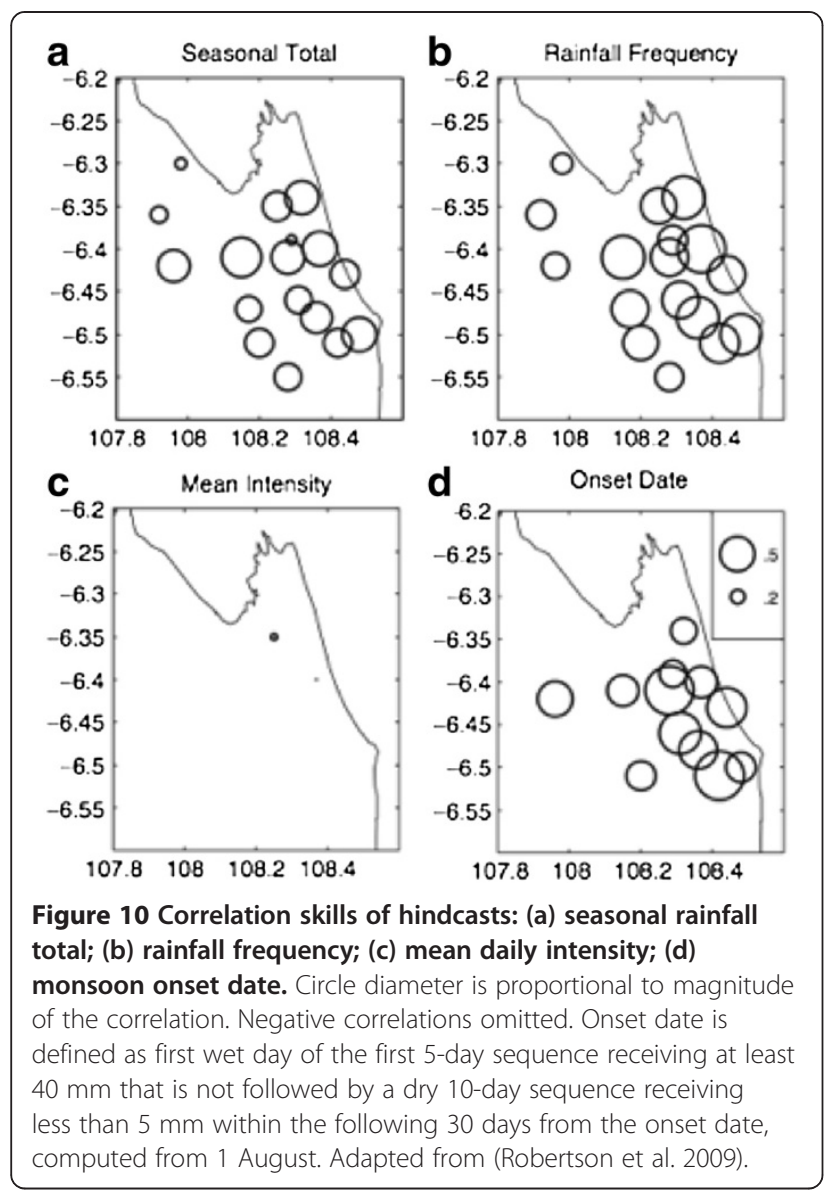

a hidden Markov model (HMM) statistical technique (Robertson et al. 2009). The skill is depicted for three different daily statistics of rainfall: rainfall frequency, mean daily intensity, monsoon onset date, in addition to the usual seasonal rainfall total. The latter is the product of rainfall frequency $\times$ mean daily intensity, and a notable result is that the seasonally predictable component of the seasonal rainfall total is found to stem almost entirely from the rainfall frequency component, with mean daily intensity having almost no predictability. In two papers (Moron et al. 2006; Moron et al. 2007) motivated by the interest in the seasonal predictability of "weather within climate", it was shown that the lack of predictability in mean daily intensity is nearly ubiquitous across the tropics, and derives from the lack of spatial coherence from station to station in seasonal anomalies of mean daily rainfall intensity, while the spatial coherence of rainfall frequency exceeds that of seasonal rainfall total; this is consistent with higher seasonal skills in rainfall frequency seen in Figure 10b compared to 10a.

The local onset date of the monsoon is defined in Figure $10 \mathrm{~d}$ from the daily rainfall time series in an agronomically relevant way, as the beginning of the first significant wet spell that is not followed by a long dry spell
(Robertson et al. 2009), using the same definition as used by the Indonesian weather service. It shows significant hindcast skill at many stations, exceeding that of the seasonal rainfall total, or even rainfall frequency. To investigate this further, Figure 11 shows the spatial coherence of interannual anomalies of rainfall quantities for 57 stations across Indonesia. Onset date and September-December seasonal rainfall total exhibit high spatial coherence. This is in stark contrast to the rainfall for the period after onset-whether averaged over the first 15 , 30 or 90 days - which show very low spatial coherence. The last bar in Figure 11 shows the residual value of seasonal rainfall total, with the onset date contribution regressed out; it too has low coherence. The results in Figure 11 demonstrate that once the monsoon begins, the amount of rainfall at the station level has very little seasonal predictability. All the seasonal predictability seen in the seasonal rainfall total during September-December is conveyed by the onset date. This is consistent with other studies that have not found much seasonal predictability of monsoon rainfall over land.

Rice planting in Indramayu district can be seriously delayed when the rainy season starts late. This causes the entire cropping calendar to be pushed back which is particularly problematic for the second rice crop, normally planted around April, that is at serious drought risk at the end of the rainy season during May-July. One of the goals of our current work with Bogor Agricultural University is to develop dynamic cropping calendars conditional on tailored climate forecasts, including of onset date.

\section{ENSO-induced rainfall dipoles over java}

Despite the much weaker impact of ENSO on seasonal rainfall during the monsoon, a pattern of rainfall anomalies does emerge in station observations over Java during the December-February of El Niño years, characterized by dry anomalies over the north coast and wet anomalies over the middle of Java island (Figure 12b). A similar pattern was identified (Giannini et al. 2007) for the January-June half year following El Niño events. However, this pattern is noisy compared to the stronger and more uniformly dry pattern during the SeptemberNovember season (Figure 12a) and both its statistical and physical significance are unclear. To gain confidence in this pattern and understand it mechanistically, longterm (1979-2000) regional climate model simulations were made over Java, driven by NCEP-NCAR reanalysis project (NNRP) data (Kalnay et al. 1996), using the RegCM3 model (Giorgi et al. 2006) with a $25 \mathrm{~km}$-resolution (Qian et al. 2010).

The El Niño-related rainfall anomalies simulated by the RegCM3 clearly reproduce the observed seasonal evolution between the transition and monsoon seasons 


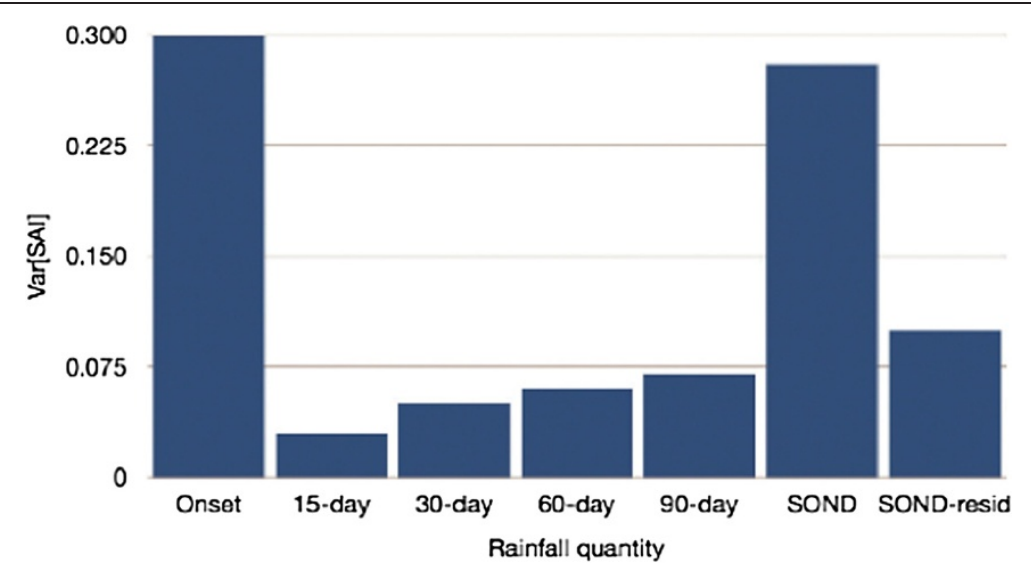

Figure 11 Interannual variance of the standardized anomaly index (SAI) across $\mathbf{5 7}$ Indonesian rainfall stations; higher variance indicates higher spatial coherence. First bar indicates onset date, with the following four bars denoting rainfall averaged in periods after local onset date; SOND = 4-month total, with right-most bar showing the residual with onset-date contribution linearly removed. (Adapted from Table 2 of (Moron et al. 2009)).

as shown in Figure 12c, d providing model-based evidence that the wet anomalies during the rainy season over central Java island are real. Further investigation of the RegCM3 simulations showed that these wet anomalies over the mountainous middle of the island are caused by an enhanced diurnal cycle with rainfall peaking in the late evening, associated with the land-sea breeze (Figure 13) that is strengthened by the influence of high topography there (demonstrated by setting the topography to zero in the simulations - see (Qian et al. 2010) for details).
Having implicated diurnal mountain-land-sea breezes in these seasonal rainfall anomalies, it still remained to understand why the diurnal cycle is enhanced during El Niño years. To understand the multi-scale interaction, daily circulation types were identified from the NNRP data used to drive the RegCM3, by means of a cluster analysis of daily wind fields (Qian et al. 2010; Moron et al. 2009). This analysis indicated that the monsoon season during El Niño years tends to be dominated by a quiescent large-scale circulation regime, and that these large-scale conditions appear to allow the diurnal cycle

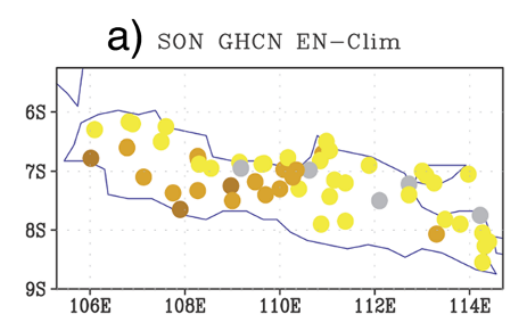

b) DJF GHCN EN-Clim

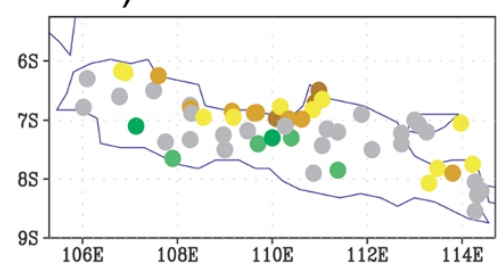

C) SON RCM EN-Clim

d) DJF RCM EN-Clim

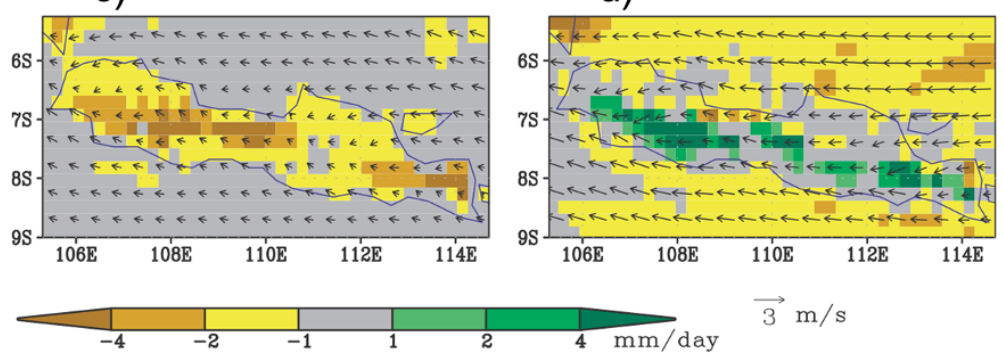

Figure 12 Composite, seasonal anomalies for El Nino years (1957/58, 1963/64, 1965/66, 1968/69, 1969/70, and 1972/73). (a), (b) Station rainfall from GHCN data for September-November and December-February. (c), (d) Precipitation and low-level wind from a regional climate model for September-November and December-February. Adapted from (Qian et al. 2010). 


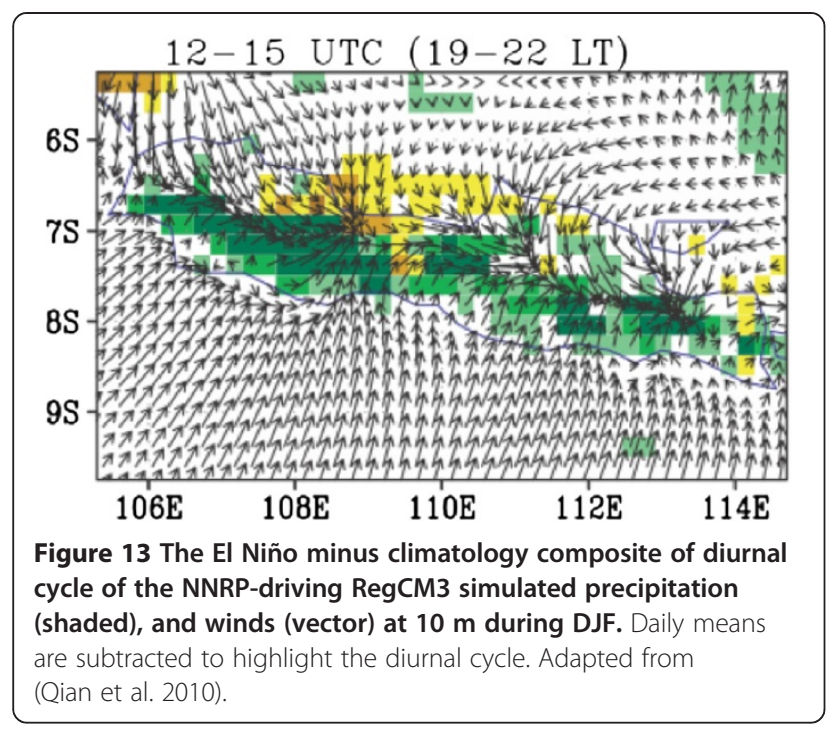

and accompanying land-sea breezes to reach higher amplitudes than when the large-scale wind field is strong (Qian et al. 2010; Moron et al. 2009). A similar phenomenon has also been isolated over Borneo (Qian et al. 2013). The larger role of regional scale processes in the December-February season compared to SeptemberNovember is also consistent with previous work (Giannini et al. 2007) where it was argued that as the tropical ocean-atmosphere equilibrates to ENSO, and ENSO itself begins to decay, regional features associated with the delayed response to ENSO become more prominent.

These diagnostic and modeling results reveal a mechanism leading to different rainfall anomalies between the coastal plains and mountainous interior of Java island. This relationship could potentially be harnessed to help make differential agricultural allocations between upland and coastal areas, for example, although the amplitude of these anomalies is smaller than those during the transition season, so that the shifts in probabilities are likely to be relatively small. Indeed, while the results suggest the potential for dynamical downscaling with the RegCM3, the associated skills are quite small (Qian pers. comm). Nonetheless, the overall diagnostic efforts undertaken in Indonesia have yielded useful information for both the agriculture and hazards (fires) sectors in the country (Moron et al. 2009).

\section{Conclusions}

This overview of just a small set of IRI climate research activities highlights the breadth and depth of the types of work being undertaken. The activities presented are all examples of targeted research undertaken for specific regions where the IRI is engaged in broader climate risk management and climate adaptation projects. In addition, the fundamental climate questions being addressed by the research were framed by climaterelated issues that arose from within those regions. Thus, addressing these fundamental climate questions ultimately has much broader implications from decisionmaking, policy and adaptation perspectives. Incorporating the knowledge gained from the climate research into these realms of course requires a larger, integrative process, as discussed elsewhere in this issue (Goddard et al. 2014).

The activity of targeted climate research as outlined in this paper is envisioned to continue as a core focus area within the IRI. Such efforts show the institution's commitment to bringing the best climate science to bear to address issues of climate risk management, adaptation and sustainability. The collaboration between IRI scientists and those from other institutions within the US and from around the globe can also lay the groundwork for future, joint initiatives. Overall, within the context of broader, regional activities focused on reducing climaterelated risks, gaining a better understanding of how the physical climate system works not only serves to enhance our basic knowledge but also to increase our ability to apply that knowledge in practical decision-making settings.

\begin{abstract}
Abbreviations
CILSS: Comité permanent Inter-Etats de Lutte contre la Sécheresse dans le Sahel; CMIP5: Coupled Model Intercomparison Project Phase 5; ENSO: El Niño-Southern Oscillation; GCM: General Circulation Model; GPCC: Global Precipitation Climatology Center; HMM: Hidden Markov Model; IRI: International Research Institute for Climate and Society; PAGASA: Philippine Atmospheric, Geophysical and Astronomical Services Administration; PRESAO: Prévisions Saisonnières en Afrique de l'Ouest; RegCM3: Regional Climate Model version 3; SESA: Southeast South America; SST: Sea Surface Temperature.
\end{abstract}

\section{Competing interests}

There are no competing interests on the parts of any of the authors.

\section{Authors' contributions}

BL wrote the section on the Philippines and synthesized contributions for the other regions written by PG, AG and AWR. All of the above authors reviewed and commented on the final version of the manuscript.

\section{Authors' information}

$\mathrm{BL}$ is a research scientist interested in climate variations on time scales from sub-seasonal to multi-decadal. He is particularly interested in drought, from understanding the physical causes underlying its development to its prediction and impacts. He has worked at the IRI since 1999 and been engaged in a number of regional projects in locations including East Africa, Southern Africa, the Philippines and Mexico. He co-teaches a climate dynamics course at Columbia University, which is one of the core courses in the curriculum of the Climate and Society Masters Program there. PG is interested in climate variability and change and climate dynamics, specifically over South America. She joined the IRI in 2010 as a postdoctoral research scientist working within the Near-Term Climate Change project and has been part of the efforts to explore decadal variability and predictability in IRI's focus regions, and to develop a framework for near-term scenarios. AG is a research scientist equally interested in elucidating the basic ingredients in tropical climate dynamics to connect understanding of variability and change, and in communicating and translating science to ensure it has a positive impact on the policy and practice of sustainable development. She has worked at the IRI since 2003, engaging in West Africa and in Southeast Asia. Together with Andy Robertson she teaches a core course in the Climate and Society program, the second semester fundamental on dynamics and impacts of regional climate. AWR is a senior research scientist and head of the climate program at the IRI. Robertson also 
leads the downscaling division within IRI and is the climate nodal person for IRI's Asia-Pacific regional program. His work is focused on bringing climate information into regional projects that seek to demonstrate the value of climate risk management, through targeted research, tool development, and both training and outreach.

\section{Acknowledgement}

Responsible editor: Hong Liao.

\section{Received: 1 October 2013 Accepted: 16 March 2014}

Published: 17 June 2014

\section{References}

ACMAD (1998) Proceedings of First Forum on Seasonal Forecasting, October 1998. Abidjan, World Meteorological Organization, WMO/TD No. 927, pp 210

Bader J, Latif M (2003) The impact of decadal-scale Indian Ocean sea surface temperature anomalies on Sahelian rainfall and the North Atlantic Oscillation. Geophys Res Lett 30:2169, doi:10.1029/2003GL018426, 22

Barnston AG, Tippett MK (2014) Climate information, outlooks, and understanding-where does the IRI stand? Earth Perspect 1:20

Barnston AG, Li S, Mason SJ, DeWitt DG, Goddard L, Gong X (2010) Verification of the first 11 years of IRI's seasonal climate forecasts. J Appl Meteorol Climatol 49:493-520

Barros VR, Doyle ME, Camilloni IA (2008) Precipitation trends in southeastern south America: relationship with ENSO phases and with low-level circulation. Theor Appl Climatol 93:19-33

Biasutti M, Giannini A (2006) Robust Sahel drying in response to late 20th century forcings. Geophys Res Lett 33, L11706, doi:10.1029/2006GL026067

Biasutti M, Held IM, Sobel AH, Giannini A (2008) SST forcings and Sahel rainfall variability in simulations of the $20^{\text {th }}$ and $21^{\text {st }}$ centuries. J Clim 21:3471-3486, doi:10.1175/2007JCLI1896.1

Camargo SJ, Sobel AH (2005) Western North Pacific tropical cyclone intensity and ENSO. J Clim 18:2996-3006

Camargo SJ, Robertson AW, Gaffney SJ, Smyth P, Ghil M (2007a) Cluster analysis of typhoon tracks. Part II: large-scale circulation and ENSO. J Clim 20:3654-3676

Camargo SJ, Emanuel KA, Sobel AH (2007b) Use of a genesis potential index to diagnose ENSO effects on tropical cyclone genesis. J Clim 20:4819-4834

Ceccato P, Nengah Surati Jaya I, Qian JH, Tippett MK, Robertson AW, Someshwar S (2010) Early warning and response to fires in Kalimantan, Indonesia. IRI Technical Report, TR10-14, pp 22

Chan JCL (1985) Tropical cyclone activity in the Northwest Pacific in relation to El Niño/Southern Oscillation phenomenon. Mon Weather Rev 113:599-606

Chan SC, Behera SK, Yamagata T (2008) Indian Ocean Dipole influence on South American rainfall. Geophys Res Lett 35:L14S12, doi:10.1029/2008GL034204

Chang C-Y, Chiang JCH, Wehner MF, Friedman AR, Ruedy R (2011) Sulfate aerosol control of Tropical Atlantic climate over the 20th century. J Clim 24:2540-2555

Charney J (1975) Dynamics of deserts and drought in the Sahel. Q J Roy Meteor Soc 101:193-202

Chen T-C, Weng S-P, Yamazaki N, Kiehne S (1998) Interannual variation in the tropical cyclone formation over the western North Pacific. Mon Weather Rev 126:1080-1090

Chia HH, Ropelewski CF (2002) The interannual variability in the genesis location of tropical cyclones in the northwest Pacific. J Clim 15:2934-2944

Diarra D, Dibi-Kangah P (2007) Agriculture in Mali. In: Climate risk management in Africa: learning from practice. 2007, Hellmuth ME, Moorhead A, Thomson MC, Williams J (eds) Climate and Society No.1. International Research Institute for Climate and Society (IRI), Columbia University, New York, USA

Emanuel KA, Nolan DS (2004) Tropical cyclone activity and global climate. Bull Am Meteorol Soc 85:666-667

Folland CK, Palmer TN, Parker DE (1986) Sahel rainfall and worldwide sea temperatures. Nature 320:602-607, 1901-85

Folland C, Owen JM, Ward MN, Colman A (1991) Prediction of seasonal rainfall in the Sahel region using empirical and dynamical methods. J Forecasting 10:21-56

Giannini A (2010) Mechanisms of climate change in the semi-arid African Sahel: the local view. J Clim 23:743-756, doi:10.1175/2009JCLI3123.1

Giannini A, Saravanan R, Chang P (2003) Oceanic forcing of Sahel rainfall on interannual to interdecadal timescales. Science 302:1027-1030, Published online 9 October 2003. doi:10.1126/science.108935
Giannini A, Saravanan R, Chang P (2005) Dynamics of the boreal summer African monsoon in the NSIPP1 atmospheric model. Clim Dynam 25:517-535, doi:10.1007/s00382-005-0056-x

Giannini A, Robertson AW, Qian J-H (2007) A role for tropical tropospheric temperature adjustment to El Nino-Southern Oscillation in the seasonality of monsoonal Indonesia precipitation predictability. J Geophys Res 112: D16110, doi:10.1029/2007JD008519

Giannini A, Biasutti M, Verstraete MM (2008) A climate model-based review of drought in the Sahel: desertification, the re-greening and climate change. Global Planetary Change 64:119-128, doi:10.1016/j.gloplacha.2008.05.004

Giannini A, Salack S, Lodoun T, Ali A, Gaye AT, Ndiaye O (2013) A unifying view of climate change in the Sahel linking intra-seasonal, interannual and longer time scales. Environ Res Lett 8:024010, doi:10.1088/1748-9326/8/2/024010

Giorgi F, Pal JS, Bi X, Sloan L, Elguindi N, Solmon F (2006) The RegCNET network. Theor Appl Climatol 86:1-4

Goddard L, Mason SJ (2002) Sensitivity of seasonal climate forecasts to persisted SST anomalies. Clim Dynam 19:619-632, doi:10.1007/s00382-002-0251-y

Goddard L, Baethgen WE, Bhojwani H, Robertson AW (2014) The International Research Institute for Climate \& Society: why, what and how. Earth Perspect 1:10

Gonzalez PLM, Goddard L, Greene AM (2012) Twentieth-Century summer precipitation in South Eastern South America: comparison of gridded and station data. Int J Climatol doi:10.1002/joc.3633

Gonzalez PLM, Polvani LM, Seager R, Correa GJP (2013) Stratospheric ozone depletion: a key driver of recent precipitation trends in South Eastern South America. Clim Dynam doi:10.1007/s00382-013-1777-x

Greene AM, Giannini A, Zebiak SE (2009) Drought return times in the Sahel: a question of attribution. Geophys Res Lett 36:L12701, doi:10.1029/2009GL038868, 2009

Greene AM, Goddard L, Cousin R (2011) Web tool deconstructs variability in twentieth-century climate. EOS Trans AGU 245:397-398

Greene AM, Hellmuth M, Lumsden T (2012) Stochastic decadal climate simulations for the Berg and Breede water management areas, western Cape province, South Africa. Water Resour Res doi:10.1029/2011WR011152

Hansen JW, Mason SJ, Sun L, Tall A (2011) Review of seasonal climate forecasting for agriculture in sub-Saharan Africa. Exp Agr 47:205-240

Haylock MR, Peterson TC, Alves LM, Ambrizzi T, Anunciacão YMT, Baez J, Barros VR, Berlato MA, Bidegain M, Coronel G, Corradi V, Garcia VJ, Grimm AM, Karoly D, Marengo JA, Marino MB, Moncunill DF, Nechet D, Quintana J, Rebello E, Rusticucci M, Santos JL, Trebejo I, Vincent LA (2006) In total and extreme South American rainfall in 1960-2000 and links with sea surface temperature. J Clim 19:1490-1512

Held I, Soden B (2006) Robust responses of the hydrological cycle to global warming. J Clim 19:5686-5699

Hendon $\mathrm{HH}$ (2003) Indonesian rainfall variability: impacts of ENSO and local air-sea interaction. J Clim 16:1775-1790

Juneng L, Tangang FT (2005) Evolution of ENSO-related rainfall anomalies in Southeast Asia region and its relationship with atmosphere-ocean variations in Indo-Pacific sector. Clim Dynam 25:337-350

Kalnay E, Kanamitsu M, Kistler R, Collins W, Deaven D, Gandin L, Iredell M, Saha S, White G, Wollen J, Zhu Y, Leetma A, Reynolds R, Chelliah M, Ebisuzaki W, Higgins W, Janowiak J, Mo KC, Ropelewski CF, Wang J, Jenne R, Joseph D (1996) The NCEP/NCAR 40-year reanalysis project. Bull Am Meteorol Soc 77:437-471

Kang SM, Polvani LM, Fyfe JC, Sigmond M (2011) Impact of polar ozone depletion on subtropical precipitation. Science 332:951-954

Kiladis GN, Diaz HF (1989) Global climatic anomalies associated with extremes in the Southern Oscillation. J Clim 2:1069-1090

Kripalani RH, Kulkarni A (1997) Rainfall variability over South-East Asia - connections with Indian monsoon and ENSO extremes: new perspectives. Int J Climatol 17:1155-1168

Liebmann B, Vera CS, Carvalho LMV, Camilloni IA, Hoerling MP, Allured D, Barros VR, Báez J, Bidegain M (2004) An observed trend in central south American precipitation. J Clim 17:4357-4367, doi:10.1175/3205.1

Lu J, Delworth TL (2005) Oceanic forcing of late $20^{\text {th }}$ century Sahel drought. Geophys Res Lett 32, L22706, doi:10.1029/2005GL023316

Lyon B (2004) The strength of El Nino and the spatial extent of tropical drought. Geophys Res Lett 31, L21204

Lyon B, Barnston AG (2005) ENSO and the spatial extent of interannual precipitation extremes in tropical land areas. J Clim 18:5095-5109

Lyon B, Camargo SJ (2009) The seasonally-varying influence of ENSO on rainfall and tropical cyclone activity in the Philippines. Clim Dynam 32:125-141 
Lyon B, Cristi H, Verceles ER, Hilario FD, Abastillas R (2006) Seasonal reversal of the ENSO rainfall signal in the Philippines. Geophys Res Lett 33, L24710, doi:10.1029/2006GL028182

Moron V, Robertson AW, Ward MN (2006) Seasonal predictability and spatia coherence of rainfall characteristics in the tropical setting of Senegal. Mon Weather Rev 134:3246-3260

Moron V, Robertson AW, Ward MN (2007) Spatial Coherence of tropical rainfall at Regional Scale. J Clim 20:5244-5263

Moron V, Robertson AW, Ward MN, Ndiaye O (2008a) Weather types and rainfall over senegal. Part I: observational analysis. J Clim 21:266-287

Moron V, Robertson AW, Ward MN, Ndiaye O (2008b) Weather types and rainfall in senegal. Part II: downscaling of GCM simulations. J Clim 21:288-307

Moron V, Robertson AW, Boer R (2009) Spatial coherence and seasonal predictability of monsoon onset over Indonesia. J Clim 22:840-850

Ndiaye O, Goddard L, Ward MN (2008) Using regional wind fields to improve general circulation model forecasts of July-September Sahel rainfall. Int J Climatol 29:1262-1275, doi:10.1002/joc.1767

Ndiaye O, Ward MN, Thiaw WM (2011) Predictability of seasonal Sahel rainfall using GCMs and lead-time improvements through the use of a coupled model. J Clim 24:1931-1949

Neelin JD, Chou C, Su H (2003) Tropical drought regions in global warming and El Niño teleconnections. Geophys Res Lett 30:2275, doi:10.1029/ 2003GL0018625

Palmer TN (1986) Influence of the Atlantic, Pacific and Indian Oceans on Sahel rainfall. Nature 322:251-253

Qian J-H, Robertson AW, Moron V (2010) Interactions between ENSO, monsoon and diurnal cycle in rainfall variability over java. Indonesia J Atmos Sci 67:3509-3523

Qian J-H, Robertson AW, Moron V (2013) Diurnal cycle in different weather regimes and rainfall variability over Borneo associated with ENSO. J Clim 26:1772-1790

Reij C, Tappan G, Belemvire A (2005) Changing land management practices and vegetation on the central plateau of Burkina Faso (1968-2002). J Arid Environ 63:642-659

Robertson AW, Moron V, Swarinoto Y (2009) Seasonal predictability of daily rainfall statistics over Indramayu district, Indonesia. Int J Climatol 29:1449-1462

Robertson AW, Baethgen W, Block P, Lall U, Sankarasubramanian A, De Assis De Souza Filho F, Verbist K (2014) Climate risk management for water in semi-arid regions. Earth Perspect, 1:12

Ropelewski CF, Halpert MS (1996) Quantifying southern oscillation precipitation relationships. J Clim 9:1043-1959

Rotstayn L, Lohmann U (2002) Tropical rainfall trends and the indirect aerosol effect. J Clim 15:2103-2116

Rowell DP (1996) Reply to comments by Sud YC, and Lau WK-M on variability of summer rainfall over tropical North Africa (1906-92): observations and modeling by Rowell DP, Folland CK, Maskell K, and Ward MN (april a, 1995 121, 669-704). Q J R Meteorol Soc 122:1007-1013

Rowell DP, Folland CK, Maskell K, Ward MN (1995) Variability of summer rainfall over tropical North Africa (1906-92): observations and modeling. Q J R Meteorol Soc 121:669-704

Saunders MA, Chandler RE, Merchant CJ, Roberts FP (2000) Atlantic hurricanes and NW Pacific typhoons: ENSO spatial impacts on occurrence and landfall. Geophys Res Lett 27:1147-1150

Seager R, Naik N, Baethgen W, Robertson AW, Kushnir Y, Nakamura J, Jurburg S (2010) Tropical oceanic causes of interannual to multidecadal precipitation variability in southeast south America over the past century. J Clim 23:5517-5539, doi:10.1175/2010JCLI3578.

Silvestri G, Vera C (2003) Antarctic oscillation signal on precipitation anomalies over southeastern South America. Geophys Res Lett 30:2115, doi:10.1029/ 2003GL018277

Tippett MK, Giannini A (2006) Potentially predictable components of African summer rainfall in an SST-forced GCM simulation. J Clim 19:3133-3144

Viglizzo E, Frank FC (2006) Ecological interactions, feedbacks, thresholds and collapses in the Argentine Pampas in response to climate and farming during the last century. Quat Int 158:122-126

Walker GT, Bliss EW (1932) World weather V. Mem R Meteorol Soc 4:53-84
Wang B, Chan JCL (2002) How strong ENSO events affect tropical storm activity over the western North Pacific. J Clim 15:1643-1658

Wang B, Zhang Q (2002) Pacific- east Asian teleconnection: Part II. How the Philippine Sea anomalous anticyclone is established during El Niño development. J Clim 15:3252-3265

Zhou J, Lau K (2001) Principal modes of interannual and decadal variability of summer rainfall over South America. Int J Climatol 21:1623-1644

doi:10.1186/2194-6434-1-18

Cite this article as: Lyon et al.: The role of targeted climate research at

the IRI. Earth Perspectives 2014 1:18

\section{Submit your manuscript to a SpringerOpen ${ }^{\odot}$ journal and benefit from:}

- Convenient online submission

- Rigorous peer review

- Immediate publication on acceptance

- Open access: articles freely available online

- High visibility within the field

- Retaining the copyright to your article

Submit your next manuscript at $>$ springeropen.com 